\title{
ANALISIS KESULITAN BELAJAR DAN MISKONSEPSI SISWA PADA POKOK BAHASAN KULTUR JARINGAN TUMBUHAN DI KELAS XI IPA SMA AS-SHOFA PEKANBARU TA 2018/2019
}

\author{
Ferni Ratna ${ }^{1)}$, Mar'atul Afidah ${ }^{2)}$ \\ Pendidikan Biologi FKIP Universitas Lancang Kuning \\ email $^{1)}$ :ferniratna4@gmail.com \\ email $^{2)}$ :maratulafidah@gmail.com
}

\begin{abstract}
ABSTRAK: Tujuan penelitian ini adalah untuk mengetahui kesulitan belajar dan miskonsepsi siswa dalam pokok bahasan kultur jaringan tumbuhan di SMA AsShofa Pekanbaru T.A.2018/2019. Penelitian ini merupakan penelitian survei dengan menggunakan teknik Total sampling yang dilaksanakan di kelas XI IPA SMA AsShofa Pekanbaru. Jumlah responden dalam penelitian ini adalah 58 orang siswa. Berdasarkan analisis persentase tingkat kesulitan belajar siswa pada pokok bahasan kultur jaringan tumbuhan sebesar 2,63 berada pada kriteria tinggi sedangkan pada persentasenya sebesar $65,76 \%$. Indikator kesulitan tertinggi adalah faktor lingkungan keluarga sebesar 2,78 berada di kriteria tinggi sedangkan persentasenya sebesar $69,50 \%$, sedangkan indikator kesulitan terendah adalah faktor jasmaniah sebesar 2,47 berada pada kriteria sedang dengan persentase $61,75 \%$. Dari hasil penelitian yang dihitung dengan teknik CRI mengalami kejadian miskonsepsi berjumlah 1276 kejadian yang terdiri dari kategori yaitu siswa yang paham dengan persentase 25,62\% ( kategori rendah), miskonsepsi dengan persentase 25,62\% (kategori rendah), tidak tahu konsep dengan persentase $27,11 \%$ (kategori rendah) dan menebak jawaban dengan persentase 21,63\% (kategori rendah) dengan skala CRI yang berbeda- beda dari 22 soal yang diujikan. Berdasarkan hasil penelitian disimpulkan bahwa seluruh indikator pada kesulitan belajar siswa berada pada kriteria sedang dan miskonsepsi pada kategori rendah.
\end{abstract}

Kata Kunci :Kesulitan Belajar, Miskonsepsi, Kultur Jaringan Tumbuhan

ABSTRACT:. The purpose of this study was to determine the learning difficulties and misconceptions of students in the subject matter of plant tissue culture in As-Shofa Pekanbaru High School T.A.2018/2019. This research is a survey research using the total sampling technique carried out in the XI IPA class of As-Shofa Pekanbaru High School. The number of respondents in this study were 58 students. Based on the analysis of the percentage of the level of learning difficulties of students on the subject of plant tissue culture amounting to 2.63 are in the high criteria while the percentage is $65.76 \%$. The highest difficulty indicator is family environmental factors of 2.78 are in high criteria while the percentage is $69.50 \%$, while the lowest difficulty indicator is physical factors of 2.47 are in the middle criteria with a percentage of $61.75 \%$. The results of the study calculated by the CRI technique experienced incidents of misconception totaling 1276 events consisting of categories of students who understood the percentage of $25.62 \%$ (low category), misconceptions with a percentage of $25.62 \%$ (low category), not knowing concepts with percentages $27.11 \%$ (low category) and guessing the answer with a percentage of $21.63 \%$ (low category) with a different CRI scale from the 22 questions tested. Based on the results of the study concluded that all indicators of student learning difficulties are in the criteria of being moderate and misconceptions in the low category.

Keywords: Learning Difficulties, Misconception, Plant Tissue Culture

Bio-Lectura: Jurnal Pendidikan Biologi, Vol 7, No 1, April 2020 


\section{PENDAHULUAN}

Pendidikan adalah salah satu bentuk perwujudan kebudayaan manusia yang dinamis dan sarat perkembangan. Oleh karena itu, perubahan atau perkembangan pendidikan adalah hal yang memang seharusnya terjadi sejalan dengan perubahan budaya kehidupan (Trianto, 2010).

Belajar adalah suatu proses usaha yang dilakukan seseorang untuk memperoleh suatu perubahan tingkah laku yang baru secara keseluruhan, sebagai hasil pengalamannya sendiri dalam interaksi dengan lingkunganya (Slameto, 2003). Menurut Akdon dan Riduwan (2005) belajar adalah suatu usaha kompleks yang terjadi pada setiap orang sepanjang hidupnya yang terjadi karena adanya interaksi antara seseorang dan lingkunganya, oleh karena itu belajar dapat terjadi kapan saja dan dimana saja yang ditandai dengan perubahan tingkah laku yang disebabkan oleh perubahan pemahaman, keterampilan, dan sikap.

Ada lima faktor yang menyebabkan miskonsepsi yaitu siswa, guru, buku teks, konteks dan metode mengajar (Suparno, 2005). Kelima faktor tersebut sangat penting untuk diperhatikan dalam pelaksanaan pembelajaran yang akan menghasilkan peserta didik yang memiiki konsep secara benar. Kesalahan miskonsepsi yang mereka terima sangat berbahaya karena akan diteruskan dari generasi kegenerasi melalui proses pembelajaran.

Siswa yang menyadari miskonsepsi yang dialaminya, akan lebih mudah untuk merubah dan memperbaiki miskonsepsinya. Siswa juga akan mampu membentuk koneksi konsep dengan sendirinya. Selain itu, siswa akan mudah memutuskan mana yang benar dan mana yang salah tentang suatu konsep. Selanjutnya, siswa juga bisa mengkonstruksi dan merekonstruksi ulang konsepsinya secara aktif. Sebelum diperbaiki, miskonsepsi harus terlebih dahulu diidentifikasi. Identifikasi miskonsepsi diperlukan dalam mengembangkan strategi untuk membentuk pengetahuan konsep yang benar pada masing-masing siswa

Kultur Jaringan merupakan suatu upaya mengisolasi bagian-bagian tanaman (protoplas, sel, jaringan, dan organ), kemudian mengkulturkannya pada nutrisi buatan yang steril dibawah kondisi lingkungan terkendali sehingga bagian-bagian tanaman 
tersebut dapat beregenerasi menjadi tanaman yang lengkap kembali.

Menurut Slameto (2010), kultur jaringan mengandung dua prinsip dasar yaitu bahan tanam yang bersifat totipotensi dan budidaya yang terkendali. Kultur jaringan adalah membudidayakan jaringan tanaman menjadi tanaman baru yang mempunyai sifat sama dengan induknya. Kultur jaringan diartikan pula dengan memelihara dan menumbuhkan organ tanaman (embrio, tunas, bunga dsb) atau jaringan tanaman (sel, kalus, protoplast) pada kondisi aseptik.

\section{Dalam menguasai konsep} tentang kultur jaringan tumbuhan. Faktor-faktor kesulitan belajar selanjutnya adalah dikarenakan jadwal atau waktunya sangat mepet dan singkat sehingga guru hanya menjelaskan materi tersebut tidak terperinci sehingga membuat murid tidak terlalu paham dengan materi kultur jaringan tumbuhan.

Sumber kesalah pahaman siswa dalam memahami sebuah konsep, dapat bersumber dari penapsiran awal yang salah pada siswa atau kesalahan yang sudah terjadi pada diri guru yang ditularkan kepada siswa. Penyampaian informasi dan pemahaman konsep yang disampaikan guru benar maka sampai kepada siswa informasi yang benar juga. Jika informasi yang disampaikan guru salah maka informasi yang disampaikan juga salah.

Dari hasil wawancara kepada guru biologi yang ada di SMA AsShofa Pekanbaru tersebut didapatkan keterangan perolehan nilai rata-rata siswa masih banyak belum mencapai KKM, berdasarkan Badan Standar Nasional Pendidikan (BSNP) yaitu 75. Dikelas XI IPA nilai rata-rata siswa pada kultur jaringan baru mencapai nilai 72. Beberapa siswa yang tidak dapat semestinya mengembangkan pemahamannya terhadap konsep kultur jaringan tumbuhan karena antara perolehan pengetahuan dengan prosesnya tidak terintegrasi dengan baik dan tidak memungkinkan siswa untuk menangkap makna secara fleksibel.

\section{METODE PENELITIAN}

Penelitian ini termasuk jenis penelitian deskriptif yang bertujuan mendeskripsikan dan menggambarkan kesulitan belajar dan miskonsepsi yang dialami siswa pada pokok bahasan kultur jaringan tumbuhan. Metode deskriptif merupakan yang tidak 
memberikan perlakuan, memanipulasi atau mengubah pada variabel variabel bebas, tetapi menggambarkan suatu kondisi apa adanya. Menurut Sugiyono (2011), penelitian deskriptif yaitu suatu metode yang digunakan untuk menganalisis dari suatu hasil tetapi tidak digunakan untuk membuat kesimpulan yang lebih luas.

\section{HASIL PENELITIAN}

\section{a. Angket Kesulitan Belajar}

Data yang diperoleh peniliti dalam profil kesulitan belajar yang menggunakan angket dengan 48 pernyataan yang terdiri dari dari 2 indikator yaitu faktor internal dengan 2 subindikator dan faktor eksternal dengan 3 subindikator. Untuk mengukur kesulitan belajar, subindikator dijadikan tolak ukur dalam melihat faktor kesulitan belajar yang dialami siswa dalam memepelajari pokok bahasan kultur jaringan tumbuhan yaitu, faktor psikologis, faktor jamaniah, faktor lingkungan keluarga, faktor lingkungan sekolah, dan faktor lingkungan masyarakat.

Tabel 1: Rekapitulasi Hasil Angket Yang Menunjukkan Kesulitan belajar

\begin{tabular}{|c|c|c|c|c|}
\hline Indikator & Sub Indikator & $\begin{array}{l}\text { Rerata } \\
\text { Skor }\end{array}$ & $\%$ & Kriteria \\
\hline \multirow[t]{2}{*}{ A. Faktor Internal } & Faktor Jasmaniah & 2,47 & 61,75 & Sedang \\
\hline & Faktor Psikologi & 2,59 & 64,75 & Sedang \\
\hline \multicolumn{2}{|c|}{ Rerata Gabungan } & 2,53 & 63,25 & Sedang \\
\hline \multirow[t]{3}{*}{ A. Faktor Eksternal } & Lingkungan Keluarga & 2,78 & 69,50 & Tinggi \\
\hline & Lingkungan Sekolah & 2,72 & 68,80 & Tinggi \\
\hline & $\begin{array}{l}\text { Lingkungan } \\
\text { Masyarakat }\end{array}$ & 2,66 & 66,50 & Tinggi \\
\hline \multicolumn{2}{|c|}{ Rerata Gabungan } & 2,72 & 68,26 & Tinggi \\
\hline \multicolumn{2}{|c|}{ Rerata Gabungan Faktor Internal dan Eksternal } & 2,63 & 65,76 & Sedang \\
\hline
\end{tabular}


Berdasarkan pada tabel diatas dapat dilihat bahwa skor rerata gabungan kesulitan belajar dalam pembelajaran kultur jaringan tumbuhan berdasarkan indikator faktor internal 2,53 berada pada kriteria sedang sedangkan persentasenya sebasar $63,25 \%$ sedangkan indikator faktor eksternal 2,72 berada pada kriteria tinggi sedangkan persentasenya sebesar $68,26 \%$.

Berikut ini adalah gambar diagram rekapitulasi skor dan persentase dari setiap indikator kesulitan belajar dapat dilihat sebagai berikut:

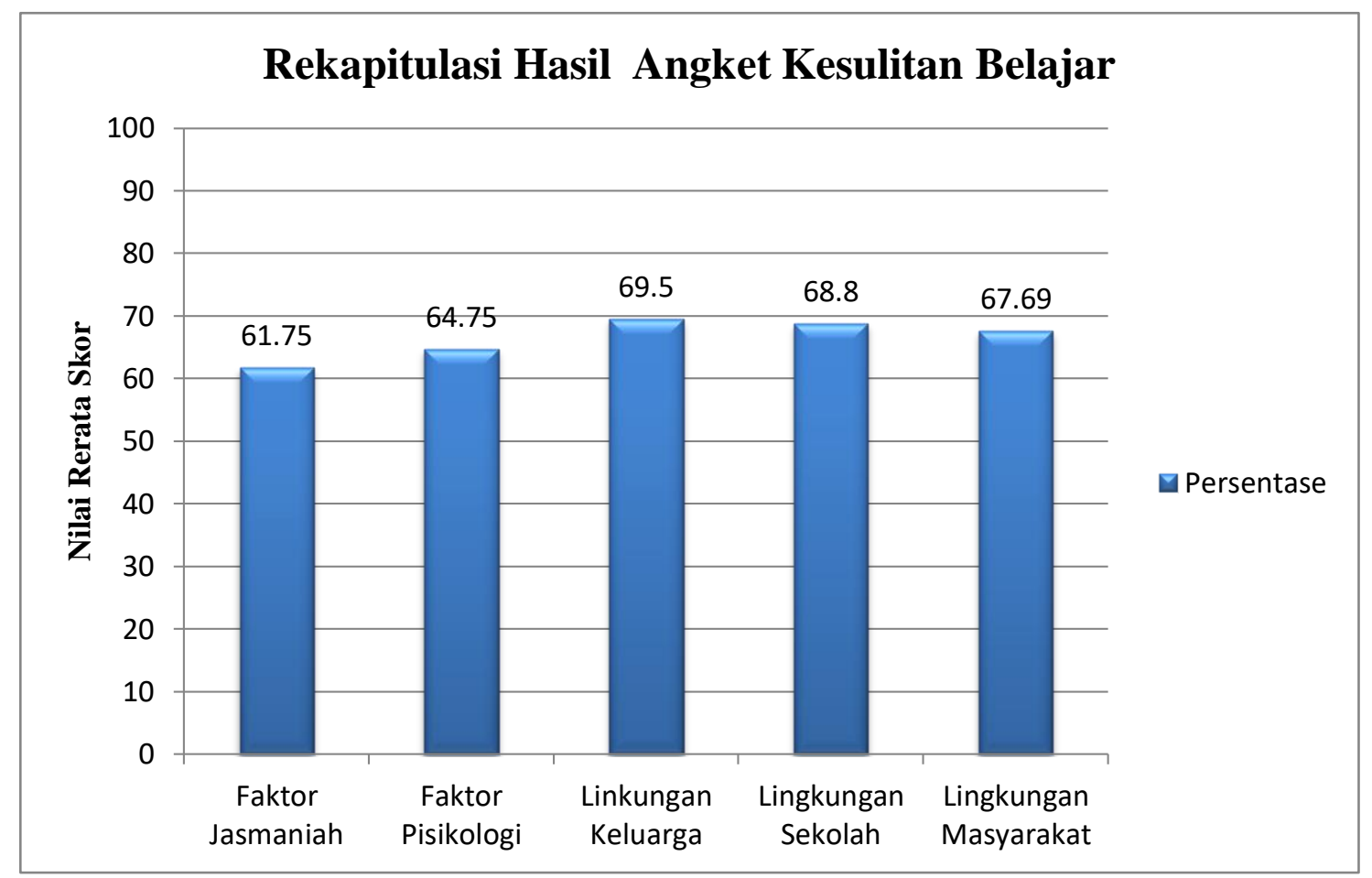

Gambar 1. Diagram Nilai Rekapitulasi Hasil Angket Kesulitan Belajar

Hasil dari setiap kategori indikator yang mempunyai perolehan tertinggi yaitu indikator factor lingkungan keluarga mencapai 2,78 $(69,50 \%)$, ditingkat selanjutnya yaitu lingkungan sekolah $2,72 \quad(68,80 \%)$, tingkat selanjutnya yaitu faktor lingkungan mencapai 2,66 (66,50\%), tingkat selanjutnya yaitu factor psikologi mencapai 2,59 (64,75\%), dan ditingkat terbawah yaitu factor jasmani mencapai 2,47 (61,75\%).

Bio-Lectura: Jurnal Pendidikan Biologi, Vol 7, No 1, April 2020 


\section{b .Data Hasil Test Miskonsepsi}

Berdasarkan hasil analisis data penelitian terdapat 58 kejadian maka diperoleh data konsepsi berjumlah 1276 kejadian yang berasal dari perhitungan jumlah siswa dikali dengan 22 butir soal yang terdiri dari 4 kategori yaitu siswa yang paham $(\mathrm{PH})$, miskonsepsi (MK), tidak tahu konsep (TPK), dan menebak (MB) dengan sekala CRI yang berbeda-beda dari 22 soal yang diujikan, untuk lebih lengkap dapat dilihat pada lampiran.

Tabel 2: Distribusi Hasil Test CRI

\begin{tabular}{|c|c|}
\hline \multicolumn{2}{|c|}{ Siswa } \\
\hline Kategori & Persentase \% \\
\hline Paham & 25,62 \\
\hline Tidak Paham Konsep & 27,11 \\
& \\
& \\
\hline Menebak & 25,62 \\
\hline Miskonsepsi & \\
\hline
\end{tabular}

Berdasarkan tabel diatas dapat dilihat bahwa persentase siswa yang paham 25,62\% (kategori rendah), persentase siswa tidak paham konsep $27,11 \%$ (kategori rendah), persentase

Bio-Lectura: Jurnal Pendidikan Biologi, Vol 7, No 1, April 2020 siswa menebak 25,62\% (kategori rendah), dan persentase siswa yang miskonsepsi 21,63\% (kategori rendah), tidak semua siswa mengalami miskonsepsi.

Secara keseluruhan hasil test diagnostic dengan menggunakan teknik CRI menunjukkan bahwa siswa mengalami miskonsespsi pada setiap butir soal. Berikut ini tabel persentase dan kategori miskonsepsi siswa pada tiap butir soal. 
Tabel 3: Persentase dan Kategori Miskonsepsi Kultur Jaringan Tumbuhan

\begin{tabular}{|c|c|c|}
\hline No & Indikator & Persentase \\
\hline 1 & $\begin{array}{l}\text { Menjelaskan pengertian teknik kultur jaringan } \\
\text { tumbuhan }\end{array}$ & $\begin{array}{l}24,13 \% \\
\text { Rendah }\end{array}$ \\
\hline 2 & $\begin{array}{c}\text { Menyebutkan macam-macam teknik kultur jaringan } \\
\text { tumbuhan }\end{array}$ & $\begin{array}{l}23,58 \% \\
\text { Rendah }\end{array}$ \\
\hline 3 & Menjelaskan manfaat dan sifat totipotensi & $\begin{array}{l}26,15 \% \\
\text { Rendah }\end{array}$ \\
\hline 4 & $\begin{array}{c}\text { Menjelaskan langkah-langkah teknik kultur jaringan } \\
\text { Tumbuhan }\end{array}$ & $\begin{array}{l}27,58 \% \\
\text { Rendah }\end{array}$ \\
\hline 5 & $\begin{array}{l}\text { Memahami manfaat, keuntungan dan kekurangan } \\
\text { teknik kultur }\end{array}$ & $\begin{array}{l}24,13 \% \\
\text { Rendah }\end{array}$ \\
\hline
\end{tabular}

Berdasarkan tabel diatas dapat dilihat bahwa siswa mengalami miskonsepsi pada setiap indikator, dan kategori yang mendominasi adalah kategori sedang. Kategori miskonsepsi tertinggi pada indikator empat dengan persentase $27,58 \%$ dan persentase terendah pada indikator dua dengan persentase 23,58\% dengan kategori rendah. Untuk lebih jelasnya dapat kita lihat pada diagram batang dibawah ini

Bio-Lectura: Jurnal Pendidikan Biologi, Vol 7, No 1, April 2020 


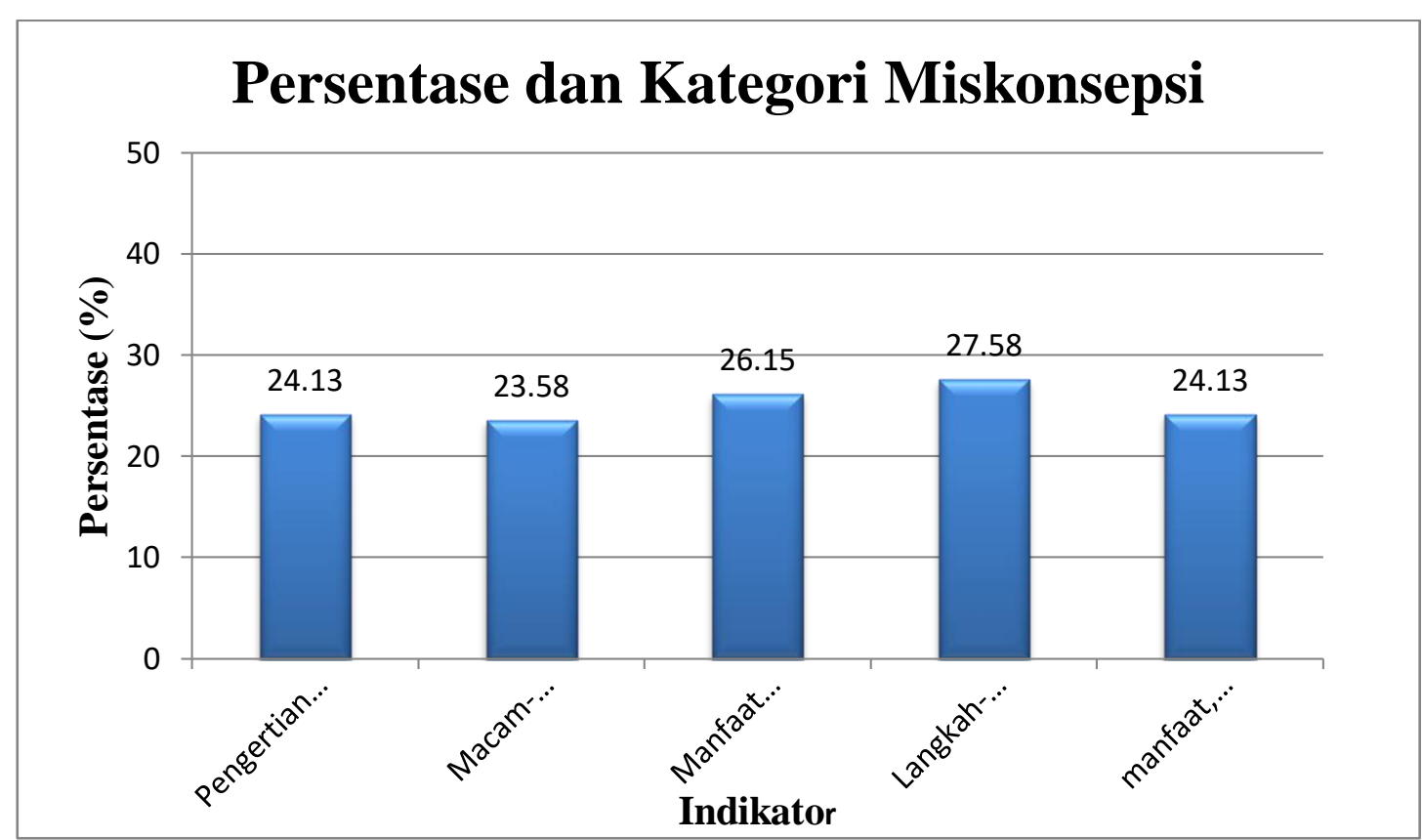

Gambar Diagram Batang Persentase Miskonsepsi Siswa Pada Tiap Indikator

Berdasarkan diagram batang persentase miskonsepsi diatas dapat dilihat bahwa para siswa banyak mengalami miskonsepsi tertinggi pada indikator manfaat, keuntungan, dan kekurangan kultur jaringan tumbuhan dengan persentase $24,13 \%$ dengan kategori rendah, selanjutnya siswa mengalami miskonsepsi pada indikator macam-macam kultur jaringan timbuhan dengan persentase $23,58 \%$ dengan kategori rendah, selanjutnya siswa mengalami miskonsepsi pada indikator langkah-langkah kultur jaringan tumbuhan dengan persentase $27,58 \%$ dengan kategori rendah, selanjutnya pada indikator manfaat dan sifat totipotensi dengan persentase 26,15\% dengan kategori rendah, dan yang terkahir pada indikator pengertian kultur jaringan tumbuhan dengan persentase $24,13 \%$ dengan kategori rendah.

Keseluruhan rerata miskonsepsi pada tiap indikator yang terjadi pada siswa ada tiga kategori yaitu rendah, sedang, dan tinggi namun dalam penelitian ini yang lebih mendominasi adalah kategori sedang. terdapat beberapa hal yang dapat menyebabkan terjadinya miskonsepsi, salah satunya adalah metode mengajar dimana miskonsepsi dapat terjadi karena pengungkapan dan konsepkonsep yang disampaikan guru tidak dapat diterima dengan baik oleh siswa sehingga menyebabkan siswa tidak mampu berkembang sesuai dengan kapasitasnya. 


\section{PEMBAHASAN}

\section{a. Angket Kesulitan Belajar}

Berdasarkan hasil penelitian yang telah dilakukan diketahui masih banyak siswa yang mengalami kesulitan belajar pada pokok bahasan kultur jaringan tumbuhan. Hal ini menandakan bahwa siswa mengalami kesulitan belajar pada pokok bahasan kultur jaringan tumbuhan. Kesulitan belajar merupakan suatu kondisi dimana peserta didik tidak dapat belajar dengan baik yang disebabkan karena adanya gangguan, baik berasal dari faktor internal siswa, faktor intelegensi maupun faktor eksternal siswa (Slameto, 2010). Fenomena kesulitan belajar seorang siswa biasanya tampak jelas dari menurunnya kinerja akdemik atau prestasi belajarnya. Disamping itu, kesulitan belajar juga dapat dibuktikan dengan adanya kelainan prilaku siswa, seperti tidak masuk sekolah dan seringnya siswa membolos/ cabut saat pelajaran sedang berlangsung. Pada dasarnya setiap orang itu memiliki perbedaan dalam hal intelektual, kebiasan atau pendekatan dalam belajar dan daya tangkap dalam menerima pelajaran, hal ini dapat kita lihat dari nilai dan prestasi yang mereka peroleh. Namun setelah angket kesulitan belajar, peneliti berikan kepada siswa masih ada sebagian siswa yang mengalami kesulitan belajar yang cukup tinggi.

Kesulitan belajar ini disebabkan oleh beberapa faktor diantaranya yaitu, faktor eksternal dan faktor internal. Hal ini sesuai dengan slameto (2010), faktor-faktor yang mempengaruhi belajar adalah jasmaniah, psikologis, keluarga, sekolah dan masyarkat. Faktor eksternal (luar), dalam hal ini yang meliputi faktor lingkungan keluarga.

Melihat secara rinci dari data hasil analisis diatas, maka kelima aspek tersebut termasuk dalam kategori tinggi. Tiga aspek yang berada pada kategori tinggi yaitu aspek lingkungan keluarga, aspek lingkungan sekolah dan aspek lingkungan masyarakat. Hal ini menunjukkan bahwa Lingkungan keluarga memberikan pengaruh besar terhadap perkembangan karakter dan mental siswa yang berdampak pada minat dan hasil belajar siswa. Semakin baik keluarga mendidik, mebimbing, dan mengajarkan siswa maka akan memberikan pengaruh besar terhadap minat dan hasil belajar siswa namun apabila keluarga memberikan 
pengajaran yang tidak bagus maka akan membuat minat dan hasil belajar siswa menjadi rendah dan siswa tidak mampu berkembang sesuai dengan kapasitasnya.

\section{b. Pembahasan Soal Miskonsepsi}

Secara keseluruhan hasil test diagnostic dengan menggunakan teknik CRI menunjukkan bahwa siswa banyak mengalami miskonsepsi pada setiap indikator.

Dari hasil analisis data penelitian ditemukan para siswa mengalami miskonsepsi tertinggi pada indikator manfaat, keuntungan, dan kekurangan kultur jaringan tumbuhan dengan rata-rata $24,15 \%$ kategori rendah. Selanjutnya manfaat dan sifat totipotensi dengan persentase $26,15 \%$ dengan kategori rendah. Selanjutnya pada indikator macam-macam kultur jaringan tumbuhan dengan rata-rata 23,58\% dengan kategori rendah. Selanjutnya pada indikator langkahlangkah teknik kultur jaringan tumbuhan dengan persentase $27,58 \%$ dengan kategori rendah. Dan yang terakhir indikator menjelaskan pengerian kultur jaringan tumbuhan dengan persentase $24,13 \%$ dengan kategori rendah.

Pada indikator satu yaitu menjelaskan pengertian kultur jaringan tumbuhan siswa mengalami miskonsepsi. Menurut Suparno (2013) miskonsepsi dapat berupa prakonsepsi yang tidak sesuai pemikiran asosiatif yang keliru, penalaran salah, intuisi yang salah, maupun kesalahan dalam menghubungkan antar konsep.

Pada indikator dua yaitu menyebutkan macam-macam kultur jaringan tumbuhan siswa juga mengalami miskonsepsi. Menurut Suparno (2013) miskonsepsi dapat bersumber dari kesalah pahaman siswa itu sendiri terhadap suatu konsep materi, kesalahan guru dalam memahami konsep, kesalahan konsep yang disajikan dalam buku teks, dan metode mengajar.

Pada indikator ketiga yaitu menjelaskan manfaat dan sifat totipotensi juga mengalami miskonsepsi. Sesuai dengan yang telah dikemukakan oleh Agustina (2017) kesalah pahaman siswa disebabkan oleh guru yang mengajar terlalu mengacu pada buku standar biologi yang telah diberikan dan wajib dipakai oleh para siswa dalam belajar maupun oleh guru ketika mengajar didalam kelas.

Pada indikator keempat yaitu menjelaskan langkah-langkah teknik kultur jaringan tumbuhan siswa juga 
mengalami miskonsepsi. Menurut Suparno (2013) penyebab terjadinya miskonsepsi pada siswa diduga karena siswa mengalami penalaran yang salah terhadap informasi dan fakta yang didapatkan tidak lengkap serta siswa kesulitan dalam mengingat dan menghafal bahasa latin.

Pada indikator lima yaitu memahami manfaat, keuntungan dan kekurangan kultur jaringan tumbuhan siswa masih banyak mengalami miskonsepsi. Menurut Wijiningsih, et all (2016) miskonsepsi pada siswa secara berulang dapat mempengaruhi penerimaan dan pemahaman siswa terhadap konsep. Guru harus mampu menjelaskan konsep kultur jaringan tumbuhan dengan benar sehingga tidak terjadi miskonsepsi yang berakibat fatal.

Adanya miskonsepsi pada siswa dapat berakibat fatal jika tidak diluruskan maka akan menyebabkan pembelajaran kultur jaringan tumbuhan tidak berkembang dengan baik. Miskonsepsi pada siswa secara berulang dapat mempengaruhi penerimaan dan pemahaman siswa terhadap konsep baru (Wijiningsih., et all, 2016). Miskonsepsi yang terjadi diduga karena konsep awal yang tidak sesuai dengan konsep ilmiah yang dibawa kependidikan formal sehingga membuat siswa tidak mampu berkembang sesuai dengan kemampuannya.

Kesulitan siswa dalam memahami buku teks dapat menjadi salah satu penyebab munculnya miskonsepsi pada siswa, karena salah satu penyebab miskonsepsi adalah dari siswa dan buku teks (Suparno, 2013). Jadi kemungkinan ada hubungannya antara kesulitan belajar siswa dengan munculnya miskonsepsi pada diri siswa dalam memahami konsep terutama pada pokok bahasan kultur jaringan tumbuhan.

\section{KESIMPULAN}

Dari hasil penelitian dapat disimpulkan bahwa kesulitan belajar dan miskonsepsi siswa pada pokok bahasan kultur jaringan tumbuhan . Faktor-faktor yang mempengaruhi kesulitan belajar siswa yang pertama yaitu faktor lingkungan keluarga mencapai $2,78 \quad(69,50 \%)$, ditingkat selanjutnya yaitu lingkungan sekolah $2,72(68,80 \%)$, tingkat selanjutnya yaitu faktor lingkungan mencapai 2,66 $(6,50 \%)$, tingkat selanjutnya yaitu factor psikologi mencapai 2,59 (64,75\%), dan ditingkat terbawah yaitu factor jasmani mencapai 2,47 $(61,75 \%)$. 
Penyebab miskonsepsi pada siswa kelas XI IPA di SMA As- Shofa Pekanbaru bahwa miskonsepsi masih terdapat pada setiap pokok bahasan kultur jaringan tumbuhan. Miskonsepsi terdapat pada semua indikator pokok bahasan kultur jaringan tumbuhan, yaitu miskonsepsi tertinggi pada indikator manfaat, keuntungan, dan kekurangan kultur jaringan tumbuhan dengan rata-rata $24,13 \%$ kategori rendah. Selanjutnya manfaat dan sifat totipotensi dengan persentase $26,15 \%$ dengan kategori rendah. Selanjutnya pada indikator macam-macam kultur jaringan tumbuhan dengan rata-rata 23,58\% dengan kategori rendah. Selanjutnya pada indikator langkahlangkah teknik kultur jaringan tumbuhan dengan persentase $27,58 \%$ dengan kategori rendah. Dan yang terakhir indikator menjelaskan pengerian kultur jaringan tumbuhan dengan persentase $24,13 \%$ dengan kategori rendah.

\section{SARAN}

Berdasarkan temuan penelitian analisis kesulitan belajar dan miskonsepsi siswa pada pokok bahasan kultur jaringan tumbuhan di kelas XI IPA SMA As - Shofa Pekanbaru tahun ajaran 2018/2019, maka peneliti memberikan saran dan rekomendasi sebagai berikut:

a. Siswa hendaknya lebih meningkatkan lagi rasa keingintahuannya terhadap pelajaran agar terciptanya pembelajaran yang lebih sempurna lagi.

b. Guru harus kreatif dalam melaksanakan proses pembelajaran agar dapat menarik perhatian siswa dalam proses pembelajaran.

c. Bagi peneliti-peneliti lain agar dapat memberikan pernyataan angket dan soal lebih mendetail dan mewakili semua aspek dan indikator kesulitan belajar dan miskonsepsi siswa agar mendapat hasil yang lebuh maksimal.

\section{DAFTAR PUSTAKA}

Abdurrahman, M. 2003. Pendidikan Bagi Anak Berkesulitan Belajar. Rineka Cipta: Jakarta.

Agustina, R., Sipahutar, H., \& Harahap,F. 2016. Analisis Miskonsepsi Pada Buku Ajar Biologi SMA Kelas XII. Jurnal Pendidikan Biologi. Vol.5. No.2 Hal. 113. 
Akdon dan Riduwan. 2005. Rumus dan Data dalam Aplikasi Statistika. Alfabeta: Bandung.

Arikunto, S. 2002. Metodologi Penelitian Suatu Pendekatan Proposal. Rineka Cipta: Jakarta.

Arikunto, S. 2009. Manajemen Penelitian. Rineka Cipta: Jakarta.

Arikunto, S. 2010. Prosedur Penelitian Suatu Pendekatan Praktik. Rineka Cipta: Jakarta.

Arikunto, S. 2011. Prosedur Penelitian: Suatu Pendekatan Praktik. Edisi Revisi VII. PT. Rineka Cipta: Jakarta.

Arikunto, S. 2015. Dasar-dasar Evaluasi Pendidikan. Bumi Aksara: Jakarta.

Gasong, D. 2018. Penerapan Strategi Pembelajaran.Deepublish:Yogyakarta.

Hakim, T. 2010. Belajar Secara Efektif (edisi 2). Puspa Swara: Jakarta.

Hakim, T. 2005. Belajar Secara Efektif. Puspa Swara: Jakara.

Hamalik, O. 2010. Proses Belajar Mengajar. PT Bumi Aksara: Jakarta.

$$
\begin{aligned}
& \text { Hendaryono,D.P.S.dan A.Wijayani. } \\
& \text { 1994. Kultur Jaringan } \\
& \text { (Pengenalan dan Petunjuk } \\
& \text { Perbanyakan Tanaman Secara } \\
& \text { Vegetatif Media). Penerbit } \\
& \text { Kanisius: Yogyakarta. }
\end{aligned}
$$

Riduwan. 2012. Metode \& Teknik Menyusun Proposal Penelitian. Alfabeta: Bandung.
Rusman. 2012. Model-model Pembelajaran:

Mengembangkan

Profesionalisme

Guru.

RajaGrafindo Persada: Jakarta.

Sardiman. 2007. Interaksi dan Motivasi Belajar Mengajar. Rajawali Pers: Bandung.

Slameto. 2010. Belajar dan Faktor yang mempengaruhinya. Rineka Cipta: Jakarta.

Suardi, M. 2015. Belajar dan pembelajaran (Edisi 1).Deepublish: Yogyakarta.

Sudjana. 2009. Penilaian Hasil Proses Belajar Mengajar. Remaja Rosdakarya: Bandung.

Sugiyono. 2007. Metode Penelitian Kuantitatif Kualitatif dan $R \&$ D. Alfabeta: Bandung.

Sugiyono. 2011. Metode Penelitian Kuantitatif, Kualitatif dan $R$ $\& D$. Afabeta: Bandung.

Sugiyono. 2015. Metode Penelitian Pendidikan (Pendekatan Kuantitatif, Kualitatif dan $R \&$ D). Alfabeta: Bandung.

Suparno. 2013. Miskonsepsi dan Perubahan Konsep Pendidikan Fisika. Grasindo: Jakarta.

Syah. 2005. Strategi Belajar Mengajar. Ciputat Press: Jakarta.

Trianto. 2010. Model Pembelajaran Terpadu. Bumi Aksara:Jakarta. 
Wijiningsih, TA. 2016. Analisis Miskonsepsi Materi StrukturFungsi Jaringan Hewan Dalam Buku Biologi SMA Kelas XI. Jurnal Pendidikan Biologi. Vol. 5 No. 7. 